Marquette University

e-Publications@Marquette

4-1-2017

\title{
Analyzing the Characteristics of Plants Choosing to Opt-Out of the Large Combustion Plant Directive
}

Andrew G. Meyer

Marquette University, andrew.g.meyer@marquette.edu

Grzegorz Pac

Alfred University

NOTICE: this is the author's version of a work that was accepted for publication in Utilities Policy. Changes resulting from the publishing process, such as peer review, editing, corrections, structural formatting, and other quality control mechanisms may not be reflected in this document. Changes may have been made to this work since it was submitted for publication. A definitive version was subsequently published in Utilities Policy, Vol. 45 (April 2017): 61-68. DOI. (C) 2017 Elsevier. Used with permission. 


\title{
Analyzing the characteristics of plants choosing to opt-out of the Large Combustion Plant Directive
}

\author{
Andrew Meyer \\ Department of Economics, Marquette University \\ Milwaukee, WI
}

\author{
Grzegors Pac \\ School of Business, Alfred University \\ Alfred, NY
}

\begin{abstract}
The EU Large Combustion Plant Directive (LCPD) is a major but largely unstudied environmental regulation. Most of the 1585 large combustion plants in this analysis are electricity supply plants or combined heat and power plants. We find that, controlling for country characteristics and plant size, plants in the electricity supply, combined heat and power, district heating, and paper industries have a higher probability of being optedout of the emission limit values (ELVs), which necessitates eventual plant closure. Controlling for plant size and industry, increasing the amount of solid fuel or natural gas utilized at a plant is associated with a decreased likelihood of being opted-out of the ELVs.
\end{abstract}

Keywords: Large combustion plant directive, Utilities, Industrial emissions

\section{Introduction}

[Utilities Policy, Vol 45, (April 2017): pg. 61-68. DOI. This article is @ [Elsevier] and permission has been granted for this version to appear in e-Publications@Marquette. [Elsevier] does not grant permission for this article to be further copied/distributed or hosted elsewhere without the express permission from [Elsevier].] 
In January 2008, the European Union (EU) implemented the Large Combustion Plant Directive (LCPD) regulation, which requires large plants to limit emissions in all member countries in order to protect the environment and improve the economic welfare of EU citizens. Starting January 1, 2008, the LCPD mandates that large combustion plants, with rated thermal inputs of 50 MWth or higher, limit emissions of sulfur dioxide, nitrogen oxide, and particulate matter (dust). The benefits of reducing these emissions include lower human exposure to pollutants that cause adverse health effects and less damage to ecosystems. However, there are compliance costs to this environmental policy, which can vary significantly by plant. Moreover, not every plant is required to respond to the LCPD in the same way. Specifically, the "limited life derogation clause" allows a plant to be "opted-out" of the LCPD emission limit values (ELVs) prescribed by the legislation provided that it will shut down after $20,000 \mathrm{~h}$ of operation. In this paper we take the first step toward quantifying the costs of the LCPD by identifying plant characteristics that associate positively with an increased probability of being opted-out of the ELVs.

Anecdotal evidence suggests that firms are choosing to shut down plants because of the LCPD. For example, E.ON UK stated that its power plants without flue gas desulphurization (FGD) would be opted-out of the directive and shut down by 2015.1 This includes the company's Ironbridge, Kingsnorth, and Grain power stations. It is unclear whether there might be an asymmetric response to the LCPD based upon the fuel mix or the size of the plant since the emission limits vary based upon these characteristics. It may be that plants of a certain type are impacted more than others. Furthermore, differences in industry structure can affect the likelihood of plants being opted-out of the LCPD.

The primary goal of this research is to examine how different industries and fuel mixes are associated with the election of the limited life derogation clause of the LCPD. The majority of plants subject to the LCPD are electricity supply plants and combined heat and power plants; it is important for policy-makers to understand whether plants in these two industries are more likely to be opted-out of the ELVs.Solid fuels such as coal have earned a reputation for causing more adverse health effects than natural gas. Yet some EU countries, such as Poland, have a robust coal mining industry that employs many

[Utilities Policy, Vol 45, (April 2017): pg. 61-68. DOI. This article is (C [Elsevier] and permission has been granted for this version to appear in e-Publications@Marquette. [Elsevier] does not grant permission for this article to be further copied/distributed or hosted elsewhere without the express permission from [Elsevier].] 
people and generates much income (Suwala, 2010; Uliasz-Bochenczyk and Mokrzycki, 2007). Hence, although it may be economically efficient to avoid health-care costs by reducing emissions from burning coal, there may also be political costs from adversely affecting the coal industry. $\underline{2}$

We construct a dataset spanning $17 \mathrm{EU}$ countries with a total of 1585 large combustion plants including all plants that were or were

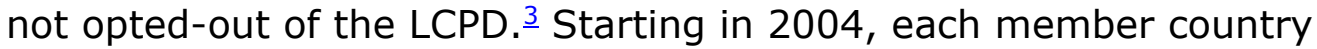
was required by the LCPD to report information on their large combustion plants. Using probit regression, we find that plants in the paper, energy supply, combined heat and power, and district heating industries have a higher probability of being opted-out of the LCPD limits. Plant characteristics are also important; larger plants have a higher probability of being opted-out while plants that use more solid fuel (such coal and lignite) and more natural gas have a lower probability of being opted-out. We also find that plants operating in less competitive markets have a lower probability of being opted-out.

Command-and-control regulations are generally considered less efficient than incentive based policies, such as a tax or tradable permits. ${ }^{4}$ An interesting aspect of the LCPD is that countries can either choose to entirely follow the command-and-control ELVs or design their own national plan that would achieve the same overall level of emission reductions. A country that designs its own incentive based policy plan should be able to achieve the emission reductions at a lower overall cost. Also, a country that incorporates an emissions tax or a tradable emissions permit system into its plan would give individual plants more flexibility to comply with regulations. Therefore, we investigate whether or not plants in countries with national emission reduction plans have lower opt-out probabilities. Six (6) of the 17 EU countries we examine (Estonia, Finland, France, Greece, Portugal, and UK) designed their own national emission plans to reduce emissions as set by the LCPD. Confirming our theoretical expectations, we find that plants in these countries are opted out at lower probabilities.

\section{Previous literature}

[Utilities Policy, Vol 45, (April 2017): pg. 61-68. DOI. This article is $\subset$ [Elsevier] and permission has been granted for this version to appear in e-Publications@Marquette. [Elsevier] does not grant permission for this article to be further copied/distributed or hosted elsewhere without the express permission from [Elsevier].] 
Policymakers regularly debate the economic effects of environmental regulation. The LCPD is an example of command-andcontrol (direct) regulation. Theoretically, command-and-control regulation has limitations, particularly in terms of potential loss of economic efficiency when marginal abatement costs differ across firms. That is, command-and-control regulation may not minimize the cost of achieving a given pollution reduction goal. Yet, "there remains a need for more empirical evidence on the economic efficiency of direct regulation" (Iraldo et al., 2011). The relationships among environmental regulation, firm performance, and economic competitiveness are complex and may vary by context ( $\mathrm{Haq}$ et al., 2001; Iraldo et al., 2011).

The LCPD is a major step towards reducing pollution in the European Union but the policy has received little academic analysis. Papers providing descriptive historical background on the LCPD include Ramus (1991) and Markusson (2012). Eames (2001) finds that countries comply with the regulation but costs associated with compliance vary at the national level. The paper was written before countries started reporting data required by European Environmental Agency (EEA) on plant emissions. Therefore, there is no analysis conducted on the effects of the directive on plants and industries.

Although we are not directly examining a causal relationship between regulation and plant exit, the limited literature on the survival or exit of polluting plants is informative. Jiang (2012) examines the US refining industry, Chen (2002) studies the decline of industry due to deregulation of crude oil markets, and Becker and Henderson (2000) show that in response to emissions regulations, plants in industries that pollute tend to close and relocate to areas with less strict regulations.

More generally, a literature review by Jeppesen and Folmer (2001) finds that stricter environmental policy is more likely to result in closure as compared to relocation of plants or reduced location of new plants. A recent survey by Millimet et al. (2009) concludes that the theoretical literature shows that increasing absolute environmental standards induces exit. Empirical evidence appears to support this. Henderson (1996) analyzes ground-level ozone regulation and finds that plants exit or relocate from areas that are more heavily regulated.

[Utilities Policy, Vol 45, (April 2017): pg. 61-68. DOI. This article is (C) [Elsevier] and permission has been granted for this version to appear in e-Publications@Marquette. [Elsevier] does not grant permission for this article to be further copied/distributed or hosted elsewhere without the express permission from [Elsevier].] 
Snyder et al. (2003) find a similar result for chlorine-manufacturing plants. Deily and Gray (1991) and Helland (1998) find that plants that are less profitable or in declining industries are less likely to be inspected and therefore have lower probability of exiting. Kassinis and Vafeas (2009) compare the environmental performance of plants prior to their closure against plants that do not close and find that plants that close are subject to more regulatory pressure and reduce their emissions more compared to plants that do not close. Yin et al. (2007) find that environmental regulation can induce small firms to exit due to economies of scale and liquidity constraints. In a comparative study of power plants in Croatia and in Bosnia and Herzegovina, Višković et al. (2014) find that differential exposure to the EU ETS negatively impacts the more heavily regulated country, Croatia, in terms of economic competitiveness. Thus, most empirical evidence suggests that increased regulation can lead to decreased firm competitiveness. Nonetheless, theories and findings are not uniform concerning the effects of environmental regulation; utilizing a Delphi method survey, Korhonen et al. (2015) find that experts view tightening of environmental regulations in the pulp and paper industry as both a threat and an opportunity to businesses. Environmental regulation as an opportunity is consistent with the "Porter induced innovation hypothesis," which states that environmental regulations spur firm innovation and hence increase firm competitiveness (Porter and van der Linde, 1995).

\section{Description of the LCPD}

The EU adopted the LCPD in October 2001, with the regulations taking effect January 2008. $\frac{5}{}$ An EU directive, the LCPD requires Member States to reduce emissions of sulphur dioxide, nitrogen oxides, and particulate matter from combustion plants with a rated thermal input of 50 MWth or more (Ritchie et al., 2005). Plants with thermal input of this scale include electricity plants, combined heat and power plants (CHP), district heating plants, oil refineries, sugar refineries, chemical manufacturers, and large industrial manufacturers (such as steelworks plants). The regulations are different for existing plants (licensed before 1 July 1987) and for new plants (licensed after July 1, 1987). For existing plants, member States can choose between complying with ELVs and implementing a national emission reduction

[Utilities Policy, Vol 45, (April 2017): pg. 61-68. DOI. This article is (C [Elsevier] and permission has been granted for this version to appear in e-Publications@Marquette. [Elsevier] does not grant permission for this article to be further copied/distributed or hosted elsewhere without the express permission from [Elsevier].] 
plan. All new plants must comply, although ELVs vary by the size of the plant and the fuel that is burned; in general, ELVs are more stringent for larger plants. Liquid fuels (such as oil) and solid fuels (such as coal) have more lenient ELVs than does natural gas.

The Czech Republic, Estonia, Finland, France, Greece, Ireland, Portugal, and the UK all submitted national emission reduction plans (Ritchie et al., 2005). This means that these Member States must reduce aggregate emissions for the country to the same levels that would have been achieved by applying the ELVs to existing plants in 2000. Relative to the situation where are all plants of a certain size and fuel type are given identical limits, this should give more flexibility to the Member States. The efficiency gains from this flexibility will theoretically depend upon the level of firm heterogeneity, with more heterogeneity leading to greater cost savings.

One exception to the LCPD regulations is the so-called "limited life derogation clause". As noted by (Ritchie et al., 2005), "an operator of an existing plant may be exempted from compliance with the ELVs (emission limit values) and from inclusion in a national emission reduction plan if a written undertaken was submitted to the competent authority by 30 June 2004, not to operate the plant for more than 20,000 operational hours starting from 1 January 2008 and ending no later than 31 December 2015". This limited life derogation clause would thus require permanent closure of the plant after $20,000 \mathrm{~h}$ of operation. To put this in perspective, a plant operating for a little less than seven hours a day would be completely shut-down by 2015 . If run continuously for $24 \mathrm{~h}$ a day, firms opting for the limited life derogation would have shut down by March of 2010.

The Industrial Emissions Directive (IED), approved by plenary vote in the European Parliament on July 7, 2010 (Nind \& Cronin, n.d.), supplanted the LCPD. The IED tightened emission limits beyond what was required by the LCPD beginning in 2016. It is important to note that the IED has no bearing on the pre-existing requirements of the LCPD (Nind \& Cronin, n.d.). That is, the LCPD is irrevocable and the plants that were opted-out of the LCPD must still have been closed by the end of 2015.

\section{Conceptual framework}

[Utilities Policy, Vol 45, (April 2017): pg. 61-68. DOI. This article is $\subset$ [Elsevier] and permission has been granted for this version to appear in e-Publications@Marquette. [Elsevier] does not grant permission for this article to be further copied/distributed or hosted elsewhere without the express permission from [Elsevier].] 
According to the standard theory of the firm, a firm will exit a competitive industry in the long run if they are realizing an economic loss. For large combustion plants, profitability is based upon plant output level, plant costs, and the price of the output good. In addition to typical fixed and variable costs, the EU plants were faced with an additional abatement cost when the LCPD went into effect. While the regulations apply to all EU plants, the limits vary based upon the characteristics of the plant. Specifically, different limits apply to plants of different sizes and fuel types. The cost of complying with identical limits may also vary from plant to plant.

In the long run, a plant is opted-out of the ELVs if projected economic profit under the ELVs $<0$. We assume that the probability of opting out of the LCPD depends upon the characteristics of the plant and a random draw. Thus, the probability of opting out due to a projected negative economic profit is represented by:

We do not directly observe price, output, capital, labor, fuel cost, competition, or abatement costs. Capital is proxied by the MWth rating of the plant. We construct a rough Herfindahl Index using total energy input to proxy competition, which also provides information about output price relative to cost. Depending on the current physical state of the plant, abatement costs may or may not drastically increase with the passage of the LCPD. Plants without FGD, for example, would face very large increases in abatement costs to comply with the $\mathrm{SO}_{2}$ limits of the directive. These plants must then project their economic profit, factoring in the increased abatement costs of installing FGD.

Some of the plants would have remained in the industry in the absence of the LCPD, but the additional LCPD abatement costs would cause them to incur an economic loss. Thus, the firm chooses to optout of the ELVs and, hence, shut down after 20,000 h of operation. However, it is likely that some plants would project an economic loss irrespective of the LCPD. We would not want to misattribute their eventually exit to the LCPD. The timing of the opt-out decision helps to separate out these two possibilities. Recall that the opt-out decision had to be submitted by 30 June 2004 but the ELVs did not apply until

[Utilities Policy, Vol 45, (April 2017): pg. 61-68. DOI. This article is @ [Elsevier] and permission has been granted for this version to appear in e-Publications@Marquette. [Elsevier] does not grant permission for this article to be further copied/distributed or hosted elsewhere without the express permission from [Elsevier].] 
2008. That is, opting-out would not provide any benefit during the years of 2004-2007. It is unlikely that a plant would be opted-out of the ELVs if it was expected to exit the industry by the end of 2007. Furthermore, we observe fuel usage and industrial emissions through 2009, so we can see if there are any plants that were opted-out of the legislation and shut-down prior to the ELVs taking effect in 2008. There is no significant difference in the percentages of opted-out plants that report 0 total energy input by 2007 (15.4\%) versus the non-opted-out plants that report 0 total energy input by 2007 (10.8\%). - However, from an ex-ante perspective in 2004, it also possible that plants with better long-range planning would plan to continue operating through 2007 but to exit in 2008 or later regardless of the LCPD. For these plants, being opted-out of ELVs in 2004 would have minimized compliance costs, but eventual exit was anticipated. Therefore, we take the position that we are analyzing the decision to opt-out plants from the ELVs and acknowledge that the opt-out choice may have been for reasons unrelated to the legislation.

One primary aim is to empirically analyze which, if any, industries have been most impacted by the LCPD opt-out decision after controlling for the size of the plant and country characteristics. Furthermore, we form several testable hypotheses regarding the characteristics of plants. All else equal, we hypothesize the following.

1.

Plants using dirtier fuels, such as coal, would face larger abatement costs to comply with the LCPD, and hence would exhibit face a higher probability of opting-out of the ELVs. For example, approximately 95 percent of the sulphur in coal is emitted as $\mathrm{SO}_{2}$ during combustion and 80 to 90 percent of ash in coal leaves the boilers along with the flue gases as particulate matter (Loyd and Craigie, 2011). Controlling these emissions generally requires installing expensive capital upgrades.

2.

Countries with national emissions reduction plans have more flexibility in how they achieve their emissions reductions than countries that rely solely on the LCPD ELVs. Hence, plants in

[Utilities Policy, Vol 45, (April 2017): pg. 61-68. DOI. This article is $\subset$ [Elsevier] and permission has been granted for this version to appear in e-Publications@Marquette. [Elsevier] does not grant permission for this article to be further copied/distributed or hosted elsewhere without the express permission from [Elsevier].] 
these countries should exhibit a lower probability of opting-out of the ELVs.

3.

Plants in less competitive industries have more market power and should be more profitable. Therefore, these plants should exhibit a lower probability of opting-out of the ELVs.

\section{Data}

The data for our analysis come directly from the European Environmental Agency (EEA). Each EU member country is responsible for tracking and reporting data to the EEA on all plants that have megawatt thermal (MWth) greater than 50. The EEA has collected several waves of the LCPD data; the first wave spans years 20042006 and the second wave includes years 2007-2009. As of January 2017, EEA has released data through 2014. ? $^{-}$Through plant matching, we combine the first two waves to obtain one dataset that includes a total of 3401 plants for the years 2004 to 2009. $\underline{8}$ The dataset contains information on various energy inputs, total energy used by plants, MWth, and plant emissions on an annual basis.

Only plants from the following 17 countries were opted-out of the LCPD: Belgium, Bulgaria, Cyprus, Denmark, Estonia, Greece, Spain, Finland, France, Latvia, Malta, Poland, Portugal, Romania, Slovenia, Slovak Republic, and United Kingdom. We therefore focus only on the 1585 plants in these countries. ${ }^{9}$ Out of these plants, 194 plants were opted out of the LCPD. Table 1 shows the breakdown of plants by country and by opt-out decision.

Table 1 . Breakdown of plants by opt-out decision in each country.

\begin{tabular}{|l|l|l|l||}
\hline Country & Not opted-out & Opted-out & Total \\
\hline \hline Belgium & 97 & 3 & 100 \\
\hline Bulgaria & 34 & 2 & 36 \\
\hline \hline Cyprus & 2 & 1 & 3 \\
\hline \hline Denmark & 30 & 2 & 32 \\
\hline
\end{tabular}

[Utilities Policy, Vol 45, (April 2017): pg. 61-68. DOI. This article is (C) [Elsevier] and permission has been granted for this version to appear in e-Publications@Marquette. [Elsevier] does not grant permission for this article to be further copied/distributed or hosted elsewhere without the express permission from [Elsevier].] 


\begin{tabular}{|l|l|l|l||}
\hline Country & Not opted-out & Opted-out & Total \\
\hline Estonia & 15 & 2 & 17 \\
\hline Finland & 182 & 21 & 203 \\
\hline \hline France & 264 & 24 & 288 \\
\hline \hline Greece & 58 & 2 & 60 \\
\hline Latvia & 26 & 3 & 29 \\
\hline Malta & 6 & 4 & 10 \\
\hline Poland & 65 & 31 & 96 \\
\hline Portugal & 24 & 3 & 27 \\
\hline Romania & 143 & 41 & 184 \\
\hline Slovakia & 67 & 9 & 76 \\
\hline \hline Slovenia & 16 & 2 & 18 \\
\hline Spain & 130 & 23 & 153 \\
\hline \hline UK & 232 & 21 & 253 \\
\hline \hline Total & 1391 & 194 & 1585 \\
\hline \hline
\end{tabular}

We identify the industry for each plant in the dataset using the reported information supplemented by a manual search. A majority of plants identified the sector in which they were operating in the second wave of the LCPD. There were six classifications given: Electricity Supply Industry (ES), Combined Heat and Power (CHP) plants, District Heating (DH), Iron and Steel, Refineries, and Other non-refineries. In total, 1336 plants were labeled with these classifications. For the missing plants and for the category of other non-refineries, we conducted a search using plant and firm websites and other sources to identify the sectors of the remaining plants. Table 2 shows the final classification of our plants by sector. The largest sectors are ES, CHP, $\mathrm{DH}$, and refineries. We also see that the ES sector has the largest number of opt-outs. In the appendix, we provide the breakdown of firms in our dataset by country and sector.

Table 2. Breakdown of plants by opt-out decision in each industry. 
NOT THE PUBLISHED VERSION; this is the author's final, peer-reviewed manuscript. The published version may be accessed by following the link in the citation at the bottom of the page.

\begin{tabular}{||l||l|l|l||}
\hline \multicolumn{1}{|c|}{ Industry } & Not opted-out & Opted-out & Total \\
\hline \hline Sugar & 48 & 3 & 51 \\
\hline Paper & 38 & 5 & 43 \\
\hline \hline Chemicals & 70 & 0 & 70 \\
\hline Refining & 151 & 3 & 154 \\
\hline Iron/Steel & 31 & 1 & 32 \\
\hline Electricity Supply (ES) & 353 & 86 & 439 \\
\hline Combined Heat and Power (CHP) & 406 & 55 & 461 \\
\hline District Heating (DH) & 143 & 37 & 180 \\
\hline Other & 73 & 4 & 76 \\
\hline \hline Other Unknown & 79 & 0 & 79 \\
\hline Total & 1391 & 194 & 1585 \\
\hline \hline
\end{tabular}

For our dependent variable we use the information on each optout decision to construct a dummy variable opt-out, which is a value of 1 if a firm decided to opt-out a plant at the beginning of 2004 and 0 if not. Emissions and energy usage must still be reported for opted-out plants because they still have $20,000 \mathrm{~h}$ to operate before they must shut down. The dataset also contains information on each plants' megawatt thermal (MWth) combustion capacity, which we use as our measure of plant size. 10 The dataset does not include information on plant output but does include various measures of energy inputs. The fuel used by plants includes biomass input, other solid fuels, liquid fuels, natural gas, and other gas. We also have total energy input for each plant (total energy input), which is obtained by summing all energy used. We note that "other solid fuels" contains coal and lignite. Table 3 provides summary statistics for each of the variables.

Table 3. Summary statistics for all variables.

\begin{tabular}{|l|l|l|l|l||l||}
\hline \multicolumn{1}{|c|}{ Variable } & Mean & Std. Dev. & Min & \multicolumn{1}{|c|}{ Max } & Obs. \\
\hline \hline MWth & 455.1 & 869.9614 & 35 & 12069 & 1519 \\
\hline \hline Biomass & 127.2 & 519.178 & 0 & 6200.598 & 1244 \\
\hline Other solid fuel & 4186 & 15196.35 & 0 & 267553.5 & 1244 \\
\hline Liquid fuel & 490.1 & 1866.198 & 0 & 38396.18 & 1244 \\
\hline
\end{tabular}

[Utilities Policy, Vol 45, (April 2017): pg. 61-68. DOI. This article is @ [Elsevier] and permission has been granted for this version to appear in e-Publications@Marquette. [Elsevier] does not grant permission for this article to be further copied/distributed or hosted elsewhere without the express permission from [Elsevier].] 


\begin{tabular}{||l||l|l|l|l|l||}
\hline \multicolumn{1}{|c|}{ Variable } & Mean & Std. Dev. & Min & Max & Obs. \\
\hline \hline Natural gas & 1739 & 5026.634 & 0 & 83749.52 & 1244 \\
\hline Other gas & 357.7 & 1256.813 & 0 & 13965.76 & 1244 \\
\hline
\end{tabular}

Note: Energy input measures are in terajoules (TJ).

We first examine whether plants that were opted-out differ in their observable characteristics from the plants that chose to remain under the ELVs of the LCPD for each industry. In Table 4, we compare these plants within each industry using the five main firm characteristics: MWth, Biomass, Other solid fuel, Liquid fuel, Natural gas, and Other gas.Table 4 shows that opted-out paper plants burn significantly more Other solid fuel than plants that would comply with the LCPD ELVs. For the refining industry, opted-out plants burn significantly less Natural gas. In the ES industry, opted-out plants burn more Liquid fuel and less Natural gas. Opted-out CHP plants tend to be larger, burn more Other solid fuel and less Biomass, Liquid fuel, and Natural gas. Finally, in the DH industry, opted-out plants are larger and burn more Other solid fuel, less Liquid fuel, and less Other gas.

Table 4. Comparing means of variables plants based on opt-out decision.

\begin{tabular}{|c|c|c|c|c|}
\hline Sector & Variable & Not Opted-Out & Opted-Out & t-test \\
\hline \multicolumn{5}{|c|}{ Sugar } \\
\hline & MWth & 116.22 & 107.39 & 0.76 \\
\hline & Biomass & $a$ & $a$ & $b$ \\
\hline & Other solid fuel & 129.33 & 245.00 & $b$ \\
\hline & Liquid fuel & 156.76 & 808.00 & $b$ \\
\hline & Natural gas & 209.94 & 0.00 & $b$ \\
\hline & Other gas & 1.97 & 0.00 & $b$ \\
\hline \multicolumn{5}{|c|}{ Paper } \\
\hline & MWth & 107.71 & 242.90 & -1.62 \\
\hline & Biomass & 532.69 & 700.95 & -0.23 \\
\hline & Other solid fuel & 268.94 & 1964.09 & $-2.72 * *$ \\
\hline
\end{tabular}

[Utilities Policy, Vol 45, (April 2017): pg. 61-68. DOI. This article is $\subset$ [Elsevier] and permission has been granted for this version to appear in e-Publications@Marquette. [Elsevier] does not grant permission for this article to be further copied/distributed or hosted elsewhere without the express permission from [Elsevier].] 
NOT THE PUBLISHED VERSION; this is the author's final, peer-reviewed manuscript. The published version may be accessed by following the link in the citation at the bottom of the page.

\begin{tabular}{|c|c|c|c|c|}
\hline Sector & Variable & Not Opted-Out & Opted-Out & $t$ t-test \\
\hline & Liquid fuel & 112.32 & 35.36 & 1.47 \\
\hline & Natural gas & 384.36 & 158.24 & 1.37 \\
\hline & Other gas & 1.07 & 4.05 & -0.71 \\
\hline \multicolumn{5}{|c|}{ Refining } \\
\hline & MWth & 224.53 & 851.33 & -1.06 \\
\hline & Biomass & $a$ & $a$ & $b$ \\
\hline & Other solid fuel & 127.42 & 0.00 & 1.00 \\
\hline & Liquid fuel & 1287.77 & 19232.06 & -0.94 \\
\hline & Natural gas & 426.97 & 0.00 & $3.23 * * *$ \\
\hline & Other gas & 1760.10 & 1284.24 & 0.49 \\
\hline \multicolumn{5}{|c|}{ Iron/Steel } \\
\hline & MWth & 219.52 & 1199.00 & $b$ \\
\hline & Biomass & $a$ & $a$ & $b$ \\
\hline & Other solid fuel & 624.75 & 6363.60 & $b$ \\
\hline & Liquid fuel & 244.79 & 244.79 & $b$ \\
\hline & Natural gas & 281.46 & 47.28 & $b$ \\
\hline & Other gas & 2826.59 & 5716.88 & $b$ \\
\hline \multicolumn{5}{|c|}{ Electricity Supply (ES) } \\
\hline & MWth & 993.93 & 1180.92 & -1.27 \\
\hline & Biomass & 118.19 & 121.95 & -0.07 \\
\hline & Other solid fuel & 10990.43 & 7918.28 & 1.21 \\
\hline & Liquid fuel & 640.48 & 1313.42 & $-2.09 * *$ \\
\hline & Natural gas & 4021.99 & 1101.47 & $4.97 * * *$ \\
\hline & Other gas & 193.03 & 379.46 & -1.08 \\
\hline \multicolumn{5}{|c|}{ Combined Heat and Power (CHP) } \\
\hline & MWth & 294.45 & 430.69 & $-1.91^{*}$ \\
\hline & Biomass & 273.46 & 10.21 & $6.40 * * *$ \\
\hline & Other solid fuel & 2407.99 & 4091.88 & $-1.78^{*}$ \\
\hline & Liquid fuel & 127.72 & 49.61 & $2.30 * *$ \\
\hline & Natural gas & 1754.26 & 354.33 & $4.92 * * *$ \\
\hline
\end{tabular}

[Utilities Policy, Vol 45, (April 2017): pg. 61-68. DOI. This article is @ [Elsevier] and permission has been granted for this version to appear in e-Publications@Marquette. [Elsevier] does not grant permission for this article to be further copied/distributed or hosted elsewhere without the express permission from [Elsevier].] 


\begin{tabular}{|c|c|c|c|c|}
\hline Sector & Variable & Not Opted-Out & Opted-Out & $t$-test \\
\hline & Other gas & 87.79 & 29.68 & 1.45 \\
\hline \multicolumn{5}{|c|}{ District Heating (DH) } \\
\hline & MWth & 139.27 & 183.87 & $-1.70 *$ \\
\hline & Biomass & 4.28 & 0.98 & 1.58 \\
\hline & Other solid fuel & 39.19 & 321.26 & $-1.85^{*}$ \\
\hline & Liquid fuel & 66.00 & 20.38 & $2.99 * * *$ \\
\hline & Natural gas & 360.47 & 272.35 & 0.70 \\
\hline & Other gas & 1.38 & 0.00 & $1.71 *$ \\
\hline
\end{tabular}

Note: Values represent means. Fuel is in terajoules (TJ). a: no observations for this industry. $b$ : too few observations within industry to conduct t-tests. *Significant at $10 \%, * *$ Significant at $5 \%$, $* * *$ Significant at $1 \%$.

We also measure firm concentration and competition for each industry and country using the Herfindahl Index. Because the dataset does not provide any output measures or sales, we use total energy input as a proxy measure to construct our Herfindahl Index. Energy input should be positively correlated with output but using energy input as proxy for output ignores differences in productivity across plants. Furthermore, we acknowledge that we only observe large plants in our analysis and the Herfindahl Index may not be appropriate for some sectors since we do not know how many firms operate in each sector. For some sectors, there may exist small firms (MWth < 50 ) that have a good portion of market share in these industries. The Herfindahl Index ranges from 0 to 1 , where industries with a value closer to 1 are generally less competitive and plants have greater market power. Table 5 summarizes the Herfindahl Index for each industry. $\underline{11}$

Table 5. Herfindahl Indices by industry.

\begin{tabular}{||l|l||l|l||}
\hline \multicolumn{1}{|c|}{ Sector } & Mean & Std. Dev. & Obs. \\
\hline \hline Sugar & 0.15 & 0.18 & 51 \\
\hline \hline Paper & 0.25 & 0.28 & 43 \\
\hline
\end{tabular}

[Utilities Policy, Vol 45, (April 2017): pg. 61-68. DOI. This article is C [Elsevier] and permission has been granted for this version to appear in e-Publications@Marquette. [Elsevier] does not grant permission for this article to be further copied/distributed or hosted elsewhere without the express permission from [Elsevier].] 


\begin{tabular}{||l|l|l|l||}
\hline \hline \multicolumn{1}{|c|}{ Sector } & Mean & Std. Dev. & Obs. \\
\hline \hline Chemicals & 0.13 & 0.19 & 69 \\
\hline Refining & 0.12 & 0.17 & 154 \\
\hline Iron/Steel & 0.38 & 0.29 & 32 \\
\hline \hline Electricity Supply (ES) & 0.06 & 0.06 & 439 \\
\hline Combined Heat and Power (CHP) & 0.06 & 0.13 & 461 \\
\hline \hline District Heating (DH) & 0.07 & 0.08 & 180 \\
\hline \hline Other & 0.12 & 0.18 & 77 \\
\hline \hline Other Unknown & 0.28 & 0.36 & 79 \\
\hline
\end{tabular}

\section{Results}

We begin by looking at the impact of the LCPD on industries as classified in Table 2. We first estimate the following probit model on a cross-section of plant level observations $\underline{12}$ :

(2)

where MWTH is the plant's size, $I_{i}$, are indicator variables for each industry, and $c_{j}$ are country controls. Our dependent variable is Optout $_{i}$, which is equal to 1 if a plant was opted-out of the LCPD and will shut down by 2015 and 0 if a plant complies with the LCPD ELVs. The results for this specification are in Table 6 . Specification I of Table 6 shows results without controlling for plant size or country differences. We drop the Refinery industry for collinearity and all coefficients presented are relative to this industry. $\frac{13}{}$ We see that the coefficients on Paper, ES, CHP, and DH industries are positive and highly significant. Thus, an average plant in these four industries has a higher probability of opting-out of the LCPD relative to plants in the Refinery industry. For example, plants in the ES industry, on average, are 30.5 percentage points more likely to be opted-out relative to Refineries.

Table 6. Probit regression results for opt-out by industry.

\begin{tabular}{||c|c||c|c||}
\hline & $\begin{array}{c}\text { Specification } \\
\text { I }\end{array}$ & $\begin{array}{c}\text { Specification } \\
\text { II }\end{array}$ & $\begin{array}{c}\text { Specification } \\
\text { III }\end{array}$ \\
\hline \hline Sugar & 0.127 & 0.133 & 0.105 \\
\hline
\end{tabular}

[Utilities Policy, Vol 45, (April 2017): pg. 61-68. DOI. This article is @ [Elsevier] and permission has been granted for this version to appear in e-Publications@Marquette. [Elsevier] does not grant permission for this article to be further copied/distributed or hosted elsewhere without the express permission from [Elsevier].] 


\begin{tabular}{|c|c|c|c|}
\hline & \begin{tabular}{|} 
Specification \\
I
\end{tabular} & \begin{tabular}{|} 
Specification \\
II
\end{tabular} & \begin{tabular}{|c|} 
Specification \\
III
\end{tabular} \\
\hline & $(0.112)$ & $(0.113)$ & $(0.108)$ \\
\hline \multirow{2}{*}{ Paper } & $0.254^{* *}$ & $0.266^{* * *}$ & $0.236^{* *}$ \\
\hline & $(0.126)$ & $(0.127)$ & $(0.127)$ \\
\hline \multirow{2}{*}{ Iron/Steel } & 0.045 & 0.046 & 0.026 \\
\hline & $(0.121)$ & $(0.122)$ & $(0.103)$ \\
\hline \multirow{2}{*}{$\begin{array}{l}\text { Electricity Supply } \\
\text { (ES) }\end{array}$} & $0.305^{* * *}$ & $0.290^{* * *}$ & $0.295^{* * *}$ \\
\hline & $(0.069)$ & $\mid(0.070)$ & $(0.069)$ \\
\hline \multirow{2}{*}{$\begin{array}{c}\text { Combined Heat and } \\
\text { Power (CHP) }\end{array}$} & $0.209^{* * *}$ & $0.214^{* * *}$ & $0.158^{* * *}$ \\
\hline & $(0.065)$ & $(0.065)$ & $(0.063)$ \\
\hline \multirow{2}{*}{$\begin{array}{c}\text { District Heating } \\
\text { (DH) }\end{array}$} & $0.371^{* * *}$ & $0.382^{* * *}$ & $0.280^{* * *}$ \\
\hline & $(0.091)$ & $(0.091)$ & $(0.097)$ \\
\hline \multirow{2}{*}{ Other } & 0.107 & 0.115 & 0.108 \\
\hline & $(0.097)$ & $(0.098)$ & $(0.096)$ \\
\hline \multirow{2}{*}{ MWth } & & $0.000019^{* *}$ & 0.0000 \\
\hline & & $(0.000)$ & $(0.000)$ \\
\hline Country FE & No & No & Yes \\
\hline Pseudo R2 & 0.052 & 0.057 & 0.107 \\
\hline Observations & 1437 & 1406 & 1406 \\
\hline
\end{tabular}

Note: Coefficients represent average marginal effects on the probability of being opted-out from the LCPD ELV's. Specifications I-III represent three specifications of the probit model given by equation (2) in the text. Standard errors are in parentheses and are robust. *Significant at $10 \%, * *$ Significant at $5 \%, * * *$ Significant at $1 \%$.

Specification II adds plant size and the sign and significance of coefficients for plants in Paper, ES, CHP, and DH industries remain similar to those in specification I. The coefficient for MWth is positive and significant implying that larger plants have a higher probability of opting-out. In Specification III, we control for country differences using a set of indicator variables and see that our results still hold. 
Next, we run our specifications to test the three hypotheses stated in the conceptual framework:

(3)

where $X$ are observable firm characteristics including MWth and fuel usage, $H_{i j}$ is the Herfindahl Index as a measure of market concentration for each industry $i$ and country $j$, and $N P_{j}$ is an indicator for plants in countries that selected to design their own national emissions reduction plans. Table 7 presents results for these three hypotheses. For our first hypothesis, we examine how fuel type impacts the opt-out decision. We see in specification I that plants burning higher levels of natural gas have a lower probability of optingout of the LCPD ELVs and plants burning higher amounts of liquid fuels have a higher probability of opting-out. Controlling for plant size, we see in specification II that the coefficients for Natural gas and Other solid fuels are also negative and significant. We see that the size of plants is also important as larger plants have a higher probability of opting-out. In specification III, we add country controls and see again that Natural gas and Other solid fuel remain negative and significant.

Table 7. Probit regression results for hypotheses 1, 2, and 3.

\begin{tabular}{|c|c|c|c|}
\hline & \begin{tabular}{|c|} 
Specification \\
I
\end{tabular} & $\begin{array}{c}\text { Specification } \\
\text { II }\end{array}$ & $\begin{array}{c}\text { Specification } \\
\text { III }\end{array}$ \\
\hline \multirow{2}{*}{ Biomass } & -0.028 & -0.037 & $-0.047^{*}$ \\
\hline & $(0.023)$ & $(0.027)$ & $(0.024)$ \\
\hline \multirow{2}{*}{ Other solid fuel } & 0.0002 & $-0.008^{* * *}$ & $-0.007^{* * *}$ \\
\hline & $(0.0005)$ & $(0.002)$ & $(0.002)$ \\
\hline \multirow{2}{*}{ Liquid fuel } & $0.010^{* *}$ & -0.0001 & 0.003 \\
\hline & $(0.004)$ & $(0.004)$ & $(0.005)$ \\
\hline \multirow{2}{*}{ Natural gas } & $-0.012^{* * *}$ & $-0.021^{* * *}$ & $-0.020^{* * *}$ \\
\hline & $(0.004)$ & $(0.005)$ & $(0.005)$ \\
\hline \multirow{2}{*}{ Other gas } & -0.015 & $-0.016^{*}$ & 0.003 \\
\hline & $(0.011)$ & $(0.010)$ & $(0.008)$ \\
\hline \multirow{2}{*}{$\begin{array}{l}\text { Herfindahl } \\
\text { Index }\end{array}$} & $-0.184^{* *}$ & $-0.158^{*}$ & -0.027 \\
\hline & $\mid(0.089)$ & $(0.083)$ & $(0.074)$ \\
\hline
\end{tabular}

[Utilities Policy, Vol 45, (April 2017): pg. 61-68. DOI. This article is $\subset$ [Elsevier] and permission has been granted for this version to appear in e-Publications@Marquette. [Elsevier] does not grant permission for this article to be further copied/distributed or hosted elsewhere without the express permission from [Elsevier].] 
NOT THE PUBLISHED VERSION; this is the author's final, peer-reviewed manuscript. The published version may be accessed by following the link in the citation at the bottom of the page.

\begin{tabular}{||c||l|l||l||}
\hline \multirow{2}{*}{ National PIan } & \multicolumn{1}{|c|}{$\begin{array}{c}\text { Specification } \\
\text { I }\end{array}$} & $\begin{array}{c}\text { Specification } \\
\text { II }\end{array}$ & \multicolumn{1}{|c||}{$\begin{array}{c}\text { Specification } \\
\text { III }\end{array}$} \\
\hline \hline \multirow{2}{*}{ MWth } & $-0.071^{* * *}$ & $-0.068^{* * *}$ & $-0.055^{* * *}$ \\
\cline { 2 - 4 } & $(0.019)$ & $(0.018)$ & $(0.018)$ \\
\cline { 2 - 4 } & & $0.0002^{* * *}$ & $0.0001^{* * *}$ \\
\hline \hline Industry FE & No & $(0.0000)$ & $(0.0000)$ \\
\hline \hline Pseudo R2 & 0.047 & No & Yes \\
\hline \hline Observations & 1244 & 0.0934 & 0.142 \\
\hline \hline
\end{tabular}

Note: Coefficients represent average marginal effects on the probability of being opted-out from the LCPD ELV's. Specifications I-III represent three specifications of the probit model given by equation (3) in the text. Variables are scaled so that all fuel variables are in petajoules. Standard errors are in parentheses and are robust. *Significant at $10 \%, * *$ Significant at $5 \%, * * *$ Significant at $1 \%$.

For our second hypothesis, we test whether plants in countries that selected national reduction plans instead of the LCPD ELVs had a lower probability of exiting. We see that the dummy variable National Plan is negative and highly significant in all three specifications of Table 7. This means that plants located in countries with national emission reduction plans have a 5.5 to 7.1 percentage point decrease in the probability of opting-out as compared plants located in countries that simply adopted the LCPD ELVs.

Finally, for our last hypothesis, we proposed that plants operating in less competitive industries will be less likely to have been opted-out. Plants in less competitive industries have generally more market power which leads to higher profit and better ability to comply with the LCPD regulation. In specification I of Table 7 the coefficient for the Herfindahl Index is negative and significant meaning that as competition decreases and firms have more market power, the probability of opting-out is reduced. This is also true in specification II where we control for plant size.

\section{Discussion}

[Utilities Policy, Vol 45, (April 2017): pg. 61-68. DOI. This article is @ [Elsevier] and permission has been granted for this version to appear in e-Publications@Marquette. [Elsevier] does not grant permission for this article to be further copied/distributed or hosted elsewhere without the express permission from [Elsevier].] 
As expected, EU large combustion plants in different industries are responding differently to the LCPD. We find that Paper, ES, CHP, and $\mathrm{DH}$ plants have an increased probability of being opted-out of the LCPD relative to Refinery plants. The marginal effect for these industries ranges from 15.9 percentage points for CHP plants in specification III of Table 6 to 38.2 percentage points for $\mathrm{DH}$ plants in specification II of Table 6 . Regardless of the reason for the decision to opt out, the future composition of these industries, especially energy utilities, will be changed because fewer plants will be in operation.

We have also stated three testable hypotheses in our conceptual framework. Regarding the first hypothesis, we find that plants that burn more natural gas and more other solid fuels (coal or lignite) have lower probabilities of opting out of the LCPD and subsequently shutting down. The finding for natural gas is expected. First, natural gas plants tend to be newer and more likely than older plants to have better pollution abatement technologies. Second, natural gas is a much cleaner burning fuel than oil or coal so, even without significant investments in pollution abatement technologies, emissions will tend to be lower than other fuel types. There are several plausible explanations for the unexpected finding for solid fuels. The ELVs specified in the LCPD are much more lenient for solid fuels than for natural gas. Policy makers wrote the law this way in part because of the inherent differences in the emissions from different fuel types. It might also be speculated that various industries, such as the coal industry, were at least marginally successful in influencing the ELVs for their fuel type. A second possible explanation is that a large portion of coal plants had already installed FGD prior to the LCPD. It is generally accepted that FGD controls between 90 and 99 percent of sulfur dioxide emissions. The $\mathrm{SO}_{2}$ ELVs, therefore, may only be binding for plants without FGD already installed. To the extent that the installation of abatement technologies has not been cost prohibitive for coal plants, the $\mathrm{SO}_{2}$ ELVs may not be stringent enough to force these plants to shut down. Similar arguments can be made for the ELVs with regard to $\mathrm{NO}_{\mathrm{x}}$ and particular matter. A third possible explanation is that many countries still have large and reliable domestic coal mines. Governments of these countries may be trying to find ways to help coal plants remain in operation. This may be especially true in countries that have state-owned coal fired plants and coal mines.

[Utilities Policy, Vol 45, (April 2017): pg. 61-68. DOI. This article is $\subset$ [Elsevier] and permission has been granted for this version to appear in e-Publications@Marquette. [Elsevier] does not grant permission for this article to be further copied/distributed or hosted elsewhere without the express permission from [Elsevier].] 
We find support for our second hypothesis regarding a national emission plan for certain countries. In Table 7, National Plan, representing plants located in Estonia, Finland, France, Greece, Portugal, and UK, is associated with a five to seven percentage point decrease in the probability of opting-out of the LCPD. This evidence suggests that plants in countries that took advantage of structuring their national emission policy may be more likely to survive. Finally, as reported in in Table 7, we find evidence in support of our third hypothesis concerning market power where we show that plants in industries with more market power have a lower probability of optingout. This is not surprising since more profitable firms should have greater ability to make the capital investments necessary to reduce emission levels as required by the LCPD ELVs.

\section{Conclusions and policy Implications}

With the enactment of the LCPD, the European Union made a significant legislative commitment to limiting pollution by large combustion plants. On the whole, this policy is expected to improve air quality for EU citizens and have a positive effect on the environment. To date, there has been little systematic analysis to determine how plants with different characteristics and in different industries are responding to the LCPD. We take the first step to better understand which plants are being "opted-out" of the LCPD ELVs under the "limited life derogation clause." These plants are required to shut down operations after 20,000 h starting in 2008.

We obtain data from the EEA for all 17 EU countries where firms opted for the "limited life derogation clause" and merge this with information about plant location, size, industry, and energy inputs. We find that plants in the Paper, ES, CHP, and DH industries have a significantly increased probability of opting-out of the LCPD ELVs and eventually shutting down. The ES, CHP, and DH industries constitute a substantial portion of combustion plants across Europe. Some countries may soon see the shutdown of many of their power generating plants (ES and CHP). For example, looking at Table 1 we see that Poland and Romania have a relatively large number of plants that have been opted-out of the ELVs and will shut down. We also see in Table A1 (appendix) that ES and CHP account for 82 out of 96

[Utilities Policy, Vol 45, (April 2017): pg. 61-68. DOI. This article is $\subset$ [Elsevier] and permission has been granted for this version to appear in e-Publications@Marquette. [Elsevier] does not grant permission for this article to be further copied/distributed or hosted elsewhere without the express permission from [Elsevier].] 
combustion plants in Poland and 71 of 184 plants in Romania. This implies that these countries may experience a reduction in conventional capacity to generate power in the coming years; they will need to take the necessary steps to make up for the loss through new domestic energy sources or imports from neighboring countries.

We find an unexpected result that the probability of a plant being opted-out and eventually closed decreases as the amount of coal or lignite burned increases. It is possible that the solid fuel ELVs are "too" lenient in the sense that it may be easier for coal plants to meet the ELVs than policy makers anticipated when writing the legislation. One piece of supporting evidence for this theory is that the new Industrial Emissions Directive (IED) significantly tightens ELVs for $\mathrm{SO}_{2}$ and particulate matter for coal plants, while leaving the ELVs unchanged for gas burning plants for these same pollutants. Consistent with economic theory, we find that plants in more concentrated industries are less likely to be opted out. Regulators considering issues of market power may want to consider this interplay between environmental regulations and firm concentration as they design and implement policy. Finally, we analyze countries that selected to use national reduction plans to achieve the goals set by the LCPD and find support that these national reduction plans may be preferred to the command-and-control approach of ELVs. This suggests that leaders of EU countries may be wise to develop national plans to comply with EU environmental regulations as these plans can give them more flexibility to meet overall targets.

We believe that more work is necessary to investigate the consequences of the LCPD policy across the EU. We have provided a first look at which plants are opted-out of the LCPD ELVs, but there remain many unanswered questions regarding the LCPD and the IED. As mentioned in the conceptual framework, one limitation of our study is that we do not know whether some of the plants that were optedout would have eventually shut down even if there were no LCPD. It is possible that some of these plants that were opted-out of the LCPD would have needed investment in order to continue operating even without LCPD emission limits. For some plants, the LCPD may have been the determining factor in the decision to shut down. At the least, our results suggest that the LCPD could be contributing to plant exit in certain industries and for certain plants. EU regulators looking for

[Utilities Policy, Vol 45, (April 2017): pg. 61-68. DOI. This article is $\subset$ [Elsevier] and permission has been granted for this version to appear in e-Publications@Marquette. [Elsevier] does not grant permission for this article to be further copied/distributed or hosted elsewhere without the express permission from [Elsevier].] 
further evidence would be wise to survey large combustion plants to learn more about the opt-out decision, including the firm's motivation for opting out of the ELVs and what would have happened to the plant in absence of the LCPD regulation. ${ }^{14}$

We also believe that more research is warranted in determining the monetary cost of achieving the LCPD ELVs for certain countries. That is, when a firm chooses to keep a plant operating, how much does it cost to achieve the required reductions in sulfur dioxide, nitrogen oxide, and particulate matter? This question has largely been answered for many countries, both on an ex-ante and ex-post basis. $\underline{15}$ However, other countries (such as Bosnia and Herzegovina) are still considering joining the EU. As a South East Europe (SEE) Programme Area country, Bosnia and Herzegovina signed a treaty to adopt and enforce the LCPD by 2017 (Dimitrijević et al., 2011; Dimitrijević and Tatić, 2012). Answering this cost question for SEE countries requires detailed information about the production processes at specific plants because the marginal costs of reducing emissions can vary widely depending on plant characteristics. $\frac{16}{}$ Additional research can provide cost estimates to compare with the benefits of required missions reduction-namely lower external costs-to find the net benefits of the legislation for specific regions or countries. We hope that our work spurs more effort to develop a more complete representation of the economic consequences of this environmental policy.

\section{Acknowledgements}

We would like to acknowledge and thank John Landi, Alexis Wheeler, and Abby Odinak for their work as research assistants.

\section{Appendix.}

Table A1. Breakdown of plants by Industry and Country

\begin{tabular}{|c|c|c|c|c|c|c|c|c|c|c|c|c|c||}
\hline $\begin{array}{c}\text { Coun } \\
\text { try }\end{array}$ & $\begin{array}{c}\text { Sug } \\
\text { ar }\end{array}$ & $\begin{array}{c}\text { Pap } \\
\text { er }\end{array}$ & $\begin{array}{c}\text { Chemi } \\
\text { cals }\end{array}$ & $\begin{array}{c}\text { Refini } \\
\text { ng }\end{array}$ & $\begin{array}{c}\text { Iron/S } \\
\text { teel }\end{array}$ & $\begin{array}{c}\text { E } \\
\text { S }\end{array}$ & $\begin{array}{c}\text { CH } \\
\text { P }\end{array}$ & $\begin{array}{c}\text { D } \\
\text { H }\end{array}$ & $\begin{array}{c}\text { Oth } \\
\text { er }\end{array}$ & $\begin{array}{c}\text { Other } \\
\text { Unkno } \\
\text { wn }\end{array}$ & $\begin{array}{c}\text { Tot } \\
\text { al }\end{array}$ \\
\hline \hline Belgiu \\
m
\end{tabular}

[Utilities Policy, Vol 45, (April 2017): pg. 61-68. DOI. This article is $\subset$ [Elsevier] and permission has been granted for this version to appear in e-Publications@Marquette. [Elsevier] does not grant permission for this article to be further copied/distributed or hosted elsewhere without the express permission from [Elsevier].] 


\begin{tabular}{|c|c|c|c|c|c|c|c|c|c|c|c|}
\hline $\begin{array}{c}\text { Coun } \\
\text { try }\end{array}$ & $\begin{array}{c}\text { Sug } \\
\text { ar }\end{array}$ & $\begin{array}{c}\text { Pap } \\
\text { er }\end{array}$ & \begin{tabular}{|c} 
Chemi \\
cals
\end{tabular} & $\mid \begin{array}{c}\text { Refini } \\
\text { ng }\end{array}$ & $\begin{array}{c}\text { Iron } / S \\
\text { teel }\end{array}$ & $\mid \begin{array}{l}\mathbf{E} \\
\mathbf{S}\end{array}$ & $\begin{array}{c}\mathbf{C H} \\
\mathbf{P}\end{array}$ & $\mid \begin{array}{l}\mathbf{D} \\
\mathbf{H}\end{array}$ & $\begin{array}{c}\text { Oth } \\
\text { er }\end{array}$ & \begin{tabular}{|c} 
Other \\
Unkno \\
wn
\end{tabular} & $\begin{array}{c}\text { Tot } \\
\text { al }\end{array}$ \\
\hline \begin{tabular}{|l|} 
Bulga \\
ria
\end{tabular} & 0 & 0 & 0 & || 2 & 1 & $\mid 4$ & 17 & || 7 & $\mid 0$ & $\mid 5$ & 36 \\
\hline \begin{tabular}{|l} 
Cypru \\
S
\end{tabular} & 0 & 0 & 0 & $\mid 0$ & 0 & || 3 & $\mid 0$ & $\mid 0$ & | 0 & $\mid 0$ & 3 \\
\hline \begin{tabular}{|l|} 
Denm \\
ark
\end{tabular} & 2 & 0 & 0 & $\mid 3$ & 0 & 0 & 26 & $\mid 0$ & $\mid 1$ & $\mid 0$ & 32 \\
\hline \begin{tabular}{|l} 
Estoni \\
a
\end{tabular} & 0 & 0 & 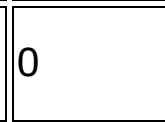 & 0 & 0 & 0 & 10 & || 7 & $\mid 0$ & $\mid 0$ & 17 \\
\hline $\begin{array}{l}\text { Finlan } \\
\text { d }\end{array}$ & 0 & 2 & | 0 & $\mid 5$ & 0 & 26 & \begin{tabular}{|l|}
15 \\
1
\end{tabular} & 15 & $\mid 0$ & || 4 & 203 \\
\hline | & 33 & 17 & |33 & 17 & 7 & 35 & 71 & 10 & $\mid 30$ & $\mid 35$ & 288 \\
\hline Greec & 0 & 0 & 0 & 9 & 2 & 47 & $\mid 1$ & $\mid 1$ & $\mid 0$ & $\|$ & 60 \\
\hline Latvia & 2 & 0 & 0 & 1 & 0 & 2 & 2 & 19 & 2 & 1 & 29 \\
\hline Malta & 0 & 0 & 0 & 0 & 0 & 10 & 0 & 0 & 0 & 0 & 10 \\
\hline \begin{tabular}{|l} 
Polan \\
d
\end{tabular} & 2 & 2 & 5 & | 2 & 2 & 27 & 55 & 0 & $\mid 1$ & $\mid 0$ & 96 \\
\hline \begin{tabular}{|l|} 
Portu \\
gal
\end{tabular} & 0 & 7 & 0 & $\mid 4$ & 0 & $\mid 10$ & |6 & 0 & $\mid 0$ & $\mid 0$ & 27 \\
\hline $\begin{array}{l}\text { Roma } \\
\text { nia }\end{array}$ & 0 & 1 & $\mid 1$ & |9 & 2 & $\mid 18$ & 53 & 94 & $\mid 4$ & $\mid 2$ & 184 \\
\hline \begin{tabular}{|l|} 
Slova \\
kia
\end{tabular} & 5 & 3 & | 2 & $\mid 1$ & 3 & $\mid 23$ & |6 & 24 & | 9 & 0 & 76 \\
\hline $\begin{array}{l}\text { Slove } \\
\text { nia }\end{array}$ & 0 & 0 & | 0 & 0 & 0 & 4 & $\mid 2$ & 3 & 0 & | 9 & 18 \\
\hline Spain & 0 & 2 & $\mid 1$ & |33 & 0 & $\begin{array}{l}10 \\
9\end{array}$ & 0 & 0 & 0 & | 8 & 153 \\
\hline UK & 5 & 8 & 14 & 50 & 10 & 94 & 39 & 0 & 20 & 13 & 253 \\
\hline |Total & 51 & 43 & |70 & 154 & 32 & $\begin{array}{l}43 \\
9 \\
\end{array}$ & \begin{tabular}{|l|}
46 \\
1 \\
\end{tabular} & $\mid \begin{array}{l}18 \\
0 \\
\end{array}$ & 76 & 79 & $\begin{array}{l}158 \\
5\end{array}$ \\
\hline
\end{tabular}

[Utilities Policy, Vol 45, (April 2017): pg. 61-68. DOI. This article is (C) [Elsevier] and permission has been granted for this version to appear in e-Publications@Marquette. [Elsevier] does not grant permission for this article to be further copied/distributed or hosted elsewhere without the express permission from [Elsevier].] 
Note: $\mathrm{ES}=$ Electricity Supply, $\mathrm{CHP}=$ Combined Heat and Power,

$\mathrm{DH}=$ District Heating.

\section{References:}

Becker and Henderson, 2000

R. Becker, V. HendersonEffects of air quality regulations on polluting industries

J. Political Econ., 108 (2) (2000), pp. 379-421, 10.1086/262123

Chen, 2002

M.-Y. ChenSurvival duration of plants: evidence from the US petroleum refining industry

Int. J. Industrial Organ., 20 (2002), pp. 517-555,

10.1016/S0167-7187(00)00106-5

ArticlePDF (220KB)

Deily and Gray, 1991

M.E. Deily, W.B. GrayEnforcement of pollution regulations in a declining industry

J. Environ. Econ. Manag., 21 (3) (1991), pp. 260-274,

10.1016/0095-0696(91)90030-M

ArticlePDF (1MB)

Dimitrijević and Tatić, 2012

Z. Dimitrijević, K. TatićThe economically acceptable scenarios for investments in desulphurization and denitrification on existing coal-fired units in Bosnia and Herzegovina

Energy Policy, 49 (2012), pp. 597-607

ArticlePDF (1MB)

Dimitrijević et al., 2011

Z. Dimitrijević, K. Tatić, A. Knežević, I. SalihbegovićExternal costs from coal-fired thermal plants and sulphur dioxide emission limit values for new plants in Bosnia and Herzegovina

Energy Policy, 39 (6) (2011), pp. 3036-3041

ArticlePDF (740KB)

Eames, 2001

$M$. EamesThe large combustion plant directive (88/609/EEC): an effective instrument for SO2 pollution abatement?

[Utilities Policy, Vol 45, (April 2017): pg. 61-68. DOI. This article is @ [Elsevier] and permission has been granted for this version to appear in e-Publications@Marquette. [Elsevier] does not grant permission for this article to be further copied/distributed or hosted elsewhere without the express permission from [Elsevier].] 
Glachant, Matthieu Ed. Implementing European Environmental Policy: the Impacts of the Directives in Member States, New Horizons in Environmental Economics, Cheltenham (2001), pp. $59-98$

Foy, 2015

$H$. FoyPoland drops mine closures in the face of union threats

ft.com January 20, 2015

Financial Times (2015)

Available:

https://www.ft.com/content/0f39388e-a07e-11e4-9aee00144feab7de

Haq et al., 2001

G. Haq, P.D. Bailey, M.J. Chadwick, J. Forrester, J.

Kuylenstierna, G. Leach, D. Villagrasa, M. Fergusson, I. Skinner,

$S$. OberthurDetermining the costs to industry of environmental regulation

Eur. Environ., 11 (3) (2001), pp. 125-139

Harrington et al., 2004

W. Harrington, R.D. Morgenstern, T. Sterner (Eds.), Choosing

Environmental Policy: Comparing Instruments and Outcomes in the United States and Europe, Resources for the Future,

Washington, D.C (2004)

Helland, 1998

E. HellandThe enforcement of pollution control laws:

inspections, violations, and self- reporting

Rev. Econ. Statistics, 80 (1) (1998), pp. 141-153

Henderson, 1996

J.V. HendersonEffects of air quality regulation

Am. Econ. Rev., 86 (4) (1996), pp. 789-813

Iraldo et al., 2011

F. Iraldo, F. Testa, M. Melis, M. FreyA literature review on the

links between environmental regulation and competitiveness

Environ. Policy Gov., 21 (3) (2011), pp. 210-222

Jeppesen and Folmer, 2001

T. Jeppesen, $\mathrm{H}$. FolmerThe confusing relationship between environmental policy and location behaviour of firms: a methodological review of selected case studies

[Utilities Policy, Vol 45, (April 2017): pg. 61-68. DOI. This article is $\subset$ [Elsevier] and permission has been granted for this version to appear in e-Publications@Marquette. [Elsevier] does not grant permission for this article to be further copied/distributed or hosted elsewhere without the express permission from [Elsevier].] 
Ann. Regional Sci., 35 (2001), pp. 523-546

Jiang, 2012

$\mathrm{S}$. JiangSurvival in the $\mathrm{U}$. S. petroleum refining industry

J. Appl. Statistics, 39 (7) (2012), pp. 1505-1530

Kassinis and Vafeas, 2009

G. Kassinis, N. VafeasEnvironmental performance and plant closure

J. Bus. Res., 62 (4) (2009), pp. 484-494,

10.1016/j.jbusres.2008.01.037

ArticlePDF (238KB)

Korhonen et al., 2015

J. Korhonen, S. Pätäri, A. Toppinen, A. TuppuraThe role of environmental regulation in the future competitiveness of the pulp and paper industry: the case of the sulfur emissions directive in Northern Europe

J. Clean. Prod., 108 (A) (2015), pp. 864-872,

10.1016/j.jclepro.2015.06.003

ArticlePDF (414KB)

Loyd and Craigie, 2011

S. Loyd, G. CraigieContinued Operation of "Opted-out"

Large Combustion Plants under the IED

Retrieved from

(2011)

www.pbworld.com

Markusson, 2012

N. MarkussonThe Politics of FGD Deployment in the UK (1980s-2009)

Energy Research Centre, UK (2012)

Retrieved from:

http://www.geos.ed.ac.uk/homes/nmarkuss/CasePols.pdf

Meyer and Pac, 2013

A. Meyer, G. PacEnvironmental performance of state-

owned and privatized eastern European energy utilities

Energy Econ., 36 (2013), pp. 205-214,

$10.1016 /$ j.eneco.2012.08.019

ArticlePDF (393KB)

Millimet et al., 2009

D.L. Millimet, S. Roy, A. SenguptaEnvironmental regulations and economic activity: influence on market structure

[Utilities Policy, Vol 45, (April 2017): pg. 61-68. DOI. This article is (C [Elsevier] and permission has been granted for this version to appear in e-Publications@Marquette. [Elsevier] does not grant permission for this article to be further copied/distributed or hosted elsewhere without the express permission from [Elsevier].] 
Annu. Rev. Resour. Econ., 1 (2009), pp. 99-117,

10.1146/annurev.resource.050708.144100

Monier and des Abbayes, 2006

V. Monier, C. des AbbayesStudy on Ex-Post Estimates of

Costs to Business of Selected Pieces of EU Environmental Legislation: case Study on the Large Combustion Plants Directive

Report to European Commission

DG Environment (2006)

Retrieved from:

http://ec.europa.eu/environment/enveco/ex post/pdf/lcpd.pdf Nind and Cronin,

Nind, A., \& Cronin, B. (n.d.). The Industrial Emissions Directive. Porter and van der Linde, 1995

M. Porter, C. van der LindeToward a new conception of the environment- competitiveness relationship

J. Econ. Perspect., 9 (4) (1995), pp. 97-118

Ramus, 1991

C.A. RamusThe Large Combustion Plant Directive: an Analysis of European Environmental Policy

Oxford Institute for Energy Studies (1991)

Retreived from

http://www.oxfordenergy.org/wpcms/wpcontent/uploads/2011/03/EV7-

TheLargeCombustionPlantDirectiveAnAnalysisofEuropeanEnviron mentalPolicy-CARasmus-1991.pdf

Ritchie et al., 2005

A. Ritchie, K. Wilson, B. Grebot, R. Smale, W. Orzeszek, S. Dann, A. StavrakakiPreparation of the Review Relating to the Large Ctive

Retrieved from (2005)

http://ec.europa.eu/environment/air/pdf/final report 05225.pdf Snyder et al., 2003

L.D. Snyder, N.H. Miller, R.N. StavinsThe effects of environmental regulation on Technology Diffusion: the case of chlorine manufacturing

Am. Econ. Rev., 93 (2) (2003), pp. 431-435

Suwala, 2010

[Utilities Policy, Vol 45, (April 2017): pg. 61-68. DOI. This article is @ [Elsevier] and permission has been granted for this version to appear in e-Publications@Marquette. [Elsevier] does not grant permission for this article to be further copied/distributed or hosted elsewhere without the express permission from [Elsevier].] 
NOT THE PUBLISHED VERSION; this is the author's final, peer-reviewed manuscript. The published version may be accessed by following the link in the citation at the bottom of the page.

\section{W. SuwalaLessons Learned from the Restructuring of} Poland's Coal-mining Industry

(Report for the Global Studies Initiative of the International Institute for Sustainable Development. Geneva, Switzerland)

(2010)

Tietenberg and Lewis, 2012

T. Tietenberg, L. LewisEnvironmental and Natural Resource

\section{Economics}

(ninth ed.), Pearson, Upper Saddle River (2012)

Uliasz-Bochenczyk and Mokrzycki, 2007

A. Uliasz-Bochenczyk, E. MokrzyckiEmissions from the Polish power industry

Energy, 32 (12) (2007), pp. 2370-2375

ArticlePDF (140KB)

Višković et al., 2014

A. Višković, V. Franki, V. ValentićEffect of regulation on power-plant operation and investment in the South East Europe Market: an analysis of two cases

Util. Policy, 30 (2014), pp. 8-17

ArticlePDF (518KB)

Yin et al., 2007

H. Yin, H. Kunreuther, M. WhiteDo Environmental

Regulations Cause Firms to Exit the Market? Evidence from Underground Storage Tank (UST) Regulations

(No. Working Paper \# 2007-10-17)

(2007)

$\underline{1}$

Please see E.ON UK website: "http://www.eonuk.com/1421.aspx".

$\underline{2}$

For a recent example of political costs related to proposed changes in the Polish mining industry, see Foy (2015).

The countries include: Belgium, Bulgaria, Cyprus, Denmark, Estonia, Greece, Spain, Finland, France, Latvia, Malta, Poland, 
Portugal, Romania, Slovenia, Slovak, Republic, and United Kingdom. No firm opted-out of the LCPD in the other 10 countries.

For a standard textbook treatment of the topic, see Tietenberg and Lewis (2012). Harrington et al. (2004) compare the cost effectiveness of various command-and-control and incentive based policies in the United States and Europe.

For more information on the LCPD please also see Meyer and Pac (2013).

30 of the opted-out plants report 0 energy input by 2007 whereas 151 of the non opted-out plants do so.

The latest data are available at http://www.eea.europa.eu/dataand-maps/data/lcp.

We use only the first two waves because we are analyzing the opt-out decision that firms needed to make by 30 June 2004. Firm attributes in more recent years may not be indicative of characteristics around the time of the opt-out decision.

This essentially forms the universe of large combustion plants for these 17 countries. However, the sample used for our regressions is somewhat smaller because observations are missing for some plants. 
NOT THE PUBLISHED VERSION; this is the author's final, peer-reviewed manuscript. The published version may be accessed by following the link in the citation at the bottom of the page.

MWth has a minimum value of 35 because there is one plant with reported 35 capacity; as a robustness check we also removed this plant and results remained consistent.

For robustness, we also use construct a second measure of Herfindahl Index using each plants' MWth; the results are consistent with Table 5.

We average the plant characteristics over the years 2004-2007. As a robustness check, we examine utilizing only data from 2004 and the results are consistent.

Plants in the chemicals industry are removed because they do not have any plants that were opted-out of the LCPD.

We attempted to administer such a survey during Spring 2013 but an extremely low response rate prevented us from addressing these issues.

See, for example, Monier and des Abbayes (2006), for comparisons of ex-ante and ex-post cost estimates for UK, Germany, Netherlands, France, Hungary, Italy, and Sweden.

Some work has begun in this realm; for example, Dimitrijević and Tatić (2012) investigate candidate DeSOx and DeNOx technologies to see which abatement methods are most cost effective at various coal-fired plants in Bosnia and Herzegovina.

[Utilities Policy, Vol 45, (April 2017): pg. 61-68. DOI. This article is $\subset$ [Elsevier] and permission has been granted for this version to appear in e-Publications@Marquette. [Elsevier] does not grant permission for this article to be further copied/distributed or hosted elsewhere without the express permission from [Elsevier].] 